AUTHORS's Proofs May 2017. To cite: Barassi Veronica..2017 'Digital Citizens? Data Traces and Family Life', selected for the Special Issue on Activism across the Life Span, Contemporary Social Science Journal. 12 (1-2), pp.84-95, ISSN 2158-2041

\title{
Digital Citizens? Data Traces and Family Life
}

Dr Veronica Barassi, Department of Media and Communications, Goldsmiths University of London v.barassi@gold.ac.uk

\section{Introduction}

Over the last ten years, the relationship between digital technologies and political participation has been a key area of research. Scholars questioned and analysed the different ways in which political activists were appropriating and using digital technologies to organise and partake into collective actions and mass protests (Gerbaudo, 2012; Cammaerts et al, 2013; Mattoni, 2012; Barassi and Treré, 2012; Barassi, 2015; Kavada, 2015; Castells, 2012; Wolfson, 2014; Postill, 2014). They also investigated the complex relationship between technological affordances and the emergence of new political repertoires of protest (Gerbaudo, 2012; Wolfson, 2014). Current research in the field of digital activism is of central importance as it highlights the fact that political participation and civic engagement have been radically transformed by digital technologies. Yet, what is missing from this body of literature is an attention towards the personal and affective dimension of online political participation.

This paper position itself within the field of media anthropology (Askew, 2002; Ginsburg et al 2002.; Brauchler and Postill, 2010) and argues that scholars have much to gain if they start reflecting not only on the relationship between political participation and digital storytelling, but also on how activists' online identity narratives are tightly interconnected to family life. Drawing on a comparative ethnography amongst activists in Italy, the UK and Spain, the paper will show that activists construct their political identities online through complex practices of digital storytelling that involve a political appropriation and reinterpretation of early childhood and family life. These practices of selfconstruction through digital storytelling, it will be shown, enable the political profiling of different family members, including children. Acknowledging these micro-practices, can enable us to appreciate not only that political socialisation in family life is being transformed by digital practices but also that these digital practices are transforming current understandings of digital participation and digital citizenship. The argument will be structured as follows. In the first part of the paper, I will explore the role family life plays in the construction of activists' identity narratives. In the second part of the paper I will proceed to explore how digital storytelling within the family is introducing new ways in which we can rethink digital participation.

\section{Identity Narratives, Family Life and the Everyday Construction of Political Subjects}


AUTHORS's Proofs May 2017. To cite: Barassi Veronica..2017 'Digital Citizens? Data Traces and Family Life', selected for the Special Issue on Activism across the Life Span, Contemporary Social Science Journal. 12 (1-2), pp.84-95, ISSN 2158-2041

\section{Political Socialisation and Family Life: The Problem of Cognitive Models of Value Transmission.}

On a winter day in 2007, I was interviewing Katie ${ }^{1}$, who at the time was in her mid-thirties and had been involved with the British Trade Union Movement since she was in her early twenties. We sat down for a long chat about her understanding of British politics and about her experience of the relationship between media technologies and political participation, which was the direct focus of my research. During the interview Katie talked about her middle-class upbringing, and told me that from a very early age she identified with working class struggles and the Labour movement.:

K: [When I was a young girl] I asked my father what was the difference between the higher classes and the working classes, and he replied that an easy way to think about it was by looking at the difference between the Sheriff of Nottingham and Robin Hood. Since then, I knew on which side to stand".

The research with Katie and the British Trade Union Movement was part of a much larger research project, which took place between 2007 and 2013, and which consisted in a cross-cultural ethnographic analysis of three different activist groups. After working with Katie's political organisation, which was involved in the Labour movement in the UK, I carried out research with other two organisations: one embedded with the Italian Autonomous movement and one with the Spanish Environmental movement. My research was largely influenced by the field of media anthropology (Askew, 2002; Ginsburg, 2002; Postill and Brauchler, 2010). As argued elsewhere (Author, 2015) the field of media anthropology distinguishes itself for three main reasons. In the first instance, it draws on the ethnography of media to understand how people negotiate with communication technologies. Subsequently, it is defined by scholars' commitment to theorise and understand media as everyday practice and as social processes (not merely as text, technologies or organizational structures). Finally, it challenges ethno-centric and techno-deterministic understandings of media's social impacts by looking at cultural variation. It was for this reason that I decided to investigate how three largely progressive and left-wing political groups, which came from very different political cultures related to web technologies. I was especially interested in the ways in which they dealt with issues of online identity construction and with the surveillance of the data they produced (Author, 2015).

Since the very early days of my research work, as Katie's interview shows, I had to come to terms with the ways in which activists understood and defined their political identity in relation to family life. This finding was of course not

\footnotetext{
${ }^{1}$ Fictional name to protect the interviewee's anonymity.
} 
AUTHORS's Proofs May 2017. To cite: Barassi Veronica..2017 'Digital Citizens? Data Traces and Family Life', selected for the Special Issue on Activism across the Life Span, Contemporary Social Science Journal. 12 (1-2), pp.84-95, ISSN 2158-2041

new. In the last fifty years, within the social sciences, different studies have argued that political beliefs are transmitted and constructed within family life (Connell, 1971, 1972; Baker, 1974; Acock and Bengtson, 1978; Jennings, 1984; Liebes and Ribak, 1992; Hess et al., 2005). Departing from different disciplinary traditions, these works were based on a variety of methodologies, which span from the use of qualitative interviews with children and parents (Connell, 1971, 1972; Liebes and Ribak, 1991) to large scale national surveys amongst children in school age (Hess et.al, 2005). In recent years we have seen the emergence of new works in the field, which drew from the earlier insights on children and political socialisation to explore the discursive construction of party politics in family life (Gordon, 2010) or the relationship between environmental activism and family values (Pettifor, 2012). All these works are of fundamental importance. It is in this body of literature that we can start appreciating how political socialisation is tightly interconnected to family life, and shed light on the fact that the political values of the family are the first cues that children learn in the shaping of their own political beliefs.

Although insightful in highlighting critical questions about political socialisation, these works remain, however, only marginally important in the study of the lived experience of political activism. Part of the problem lies in the fact that this literature focuses too much on the cognitive/ rational dimension of political formation. By investigating the way in which political participation is shaped by values and beliefs, these scholars explore how political values are transmitted through the family.

There is no doubt that one important dimension of the making of political subjects needs to be found in political values and beliefs, and the way in which activists develop a sense of social justice that it constructed within the family. My interview with Katie revealed precisely that: Katie had developed her own political values following the teachings learned from her father. However, my own research also revealed that there is much more to 'the making of political subjects' in family life, which has less to say about the transmission of 'political values' from parents to children, and more to say about the very subjective and affective dimension of 'being political' (Fenton, 2016). Of course, the study of the 'affective dimension' of political participation involves acknowledging the complexity of emotions that are triggered by one's own sense of the political. These include anger, solidarity, nostalgia, fear and many other different emotions, which could lead to very different political consequences. When talking about the 'affective dimension' of political participation, the aim of this paper is not to shed light on the complexities of political emotions or their consequences. Rather the aim of this paper is to highlight how political identities are often constructed through affective processes of meaning construction in relation to early childhood 
AUTHORS's Proofs May 2017. To cite: Barassi Veronica..2017 'Digital Citizens? Data Traces and Family Life', selected for the Special Issue on Activism across the Life Span, Contemporary Social Science Journal. 12 (1-2), pp.84-95, ISSN 2158-2041

and family life. The paper will thus show not only that political identities are tightly interconnected to the construction of biographical narratives that emerge within the family (Nolas et. al, 2016) but also how these biographical narratives are shaped by messy and affective processes of storytelling.

\section{Identity Narratives and Family Life}

The relationship between political identity, biographical experiences and narrative construction was a key element of my research design. My own research methods were influenced by the belief that one particular problem of ethnographic research relates to the fact that - as Dewalt and Dewalt (2002) mentioned - with participant observation alone it is unlikely that the ethnographer will gain historical depth. Hence I enriched my ethnographic work with 87 semistructured interviews, which were all based on the life history method (Alleyene,2000; Hastrup and Davis, 1992). My intention was to understand activists' biographical experience and path to political involvement, and to explore the way in which they experienced technological change. The choice of focusing on activists' life narratives was motivated by the belief that the life histories approach in the study of activism is particularly important, as it can provide the researcher not only with an historical dimension, but also with insights concerning the way in which people internalise collective repertoires of the past (Tilly, 1994:244).

It was thanks to the life history method that I collected a variety of testimonies that highlighted the social complexities that define the relationship between family life, political identity construction, and biographical narratives. Over and over again when asked to explain how they became politically involved, the activists I interviewed not only mentioned the importance of family life in their political development, but also seemed to assume that the connection between one's own family life and and political identity was inevitable. One day in 2011, I sat down for an interview with Marta ${ }^{2}$ in the garden of the 'Autonomous Zone Milan' (Zona Autonoma Milanese, ZAM). Marta, who was in her late twenties, described her path to political involvement, departing from her family:

"My father was a trade unionist, my mother a politically engaged teacher. I grew up feeling politics, breathing politics, and believing that politics is not about parties, and institutions but rather about social experience and commitment. If you look at my family, and my past, it's obvious why I am politically engaged".

Marta's interview was interesting, as it highlighted the fact that 'being political' - as Fenton (2016) rightly argues - does not only relate to rational political values, but it's a complex experiential process defined by an affective

\footnotetext{
${ }^{2}$ Fictional name to protect the interviewee's anonymity.
} 
AUTHORS's Proofs May 2017. To cite: Barassi Veronica..2017 'Digital Citizens? Data Traces and Family Life', selected for the Special Issue on Activism across the Life Span, Contemporary Social Science Journal. 12 (1-2), pp.84-95, ISSN 2158-2041

dimension. Marta, in fact, did not share the same political values of her family. In contrast to her father who was a Trade Unionist, she identified much more with forms of grassroots politics, and she was deeply influenced by the autonomists and anarchist discourses that emerged during the global justice movements in the 1990s (Holloway, 2002; Day, 2005). However, she believed that she had inherited from her family a 'sense of the political' and she constructed her political identity through a complex biographical narrative, which started precisely from that 'feeling of the political' acquired during childhood. In order to investigate the affective role family life plays in the construction of one's political identity, therefore, we need to appreciate the intricate interstices of biographical narratives and political identity construction.

Here the concept of 'political identity' as discussed in the anthropology of social movements (Pratt, 2003; Escobar, 2004) is particularly insightful. According to Escobar political identity needs to be detached from fixed notions of 'identity politics' that dominate early social movements research, and instead needs to be understood as a relational concept, a concept which defines both selfconsciousness and participation to communities of imagination and practice (Escobar, 2004). Identity, is therefore, not something carried as a definer of the individual, but a process of self-imagination, which is constantly constructed though the everyday practice in the encounter of groups (Escobar, 2004:252).

This process of self-imagination and identity construction is tightly interconnected to the process of storytelling. In the anthropology of social movements, Pratt (2003) was perhaps one of the first to highlight this relationship. He argued that in the study of social movements and political activism, we have much to gain if we approach the understanding of identity as narrative and appreciate how this narrative develops on two different, albeit interconnected, axes. On the one hand, identity narratives are constructed through the hierarchical axis, which suggests who 'we' are, through opposition and the creation of the other. On the other hand, identity narratives are constructed through the biographical axis, which establishes who people are through the medium of time (2003:10). The biographical axis is thus the process whereby activists, like Marta or Katie, construct themselves by reflecting on their experience of the political since early childhood.

In Pratt's (2003) work, therefore, it becomes clear that biographical narratives, which emerge within the family are a fundamental aspect of political identity. Yet within the social movements literature there is little exploration of this relationship. Most of the works on political identities focus on the hierarchical axis of identity narratives, hence on the multiple ways in which activists define their sense of belonging to a group in opposition to 'other' groups. The works of Alleyene on black activists (2000) and of Nolas et al. (2016), constitute perhaps the major exceptions to this trend. In fact, within their work the scholars 
AUTHORS's Proofs May 2017. To cite: Barassi Veronica..2017 'Digital Citizens? Data Traces and Family Life', selected for the Special Issue on Activism across the Life Span, Contemporary Social Science Journal. 12 (1-2), pp.84-95, ISSN 2158-2041

insightfully explore the lived experience of activism, by looking at the interconnection between family life and biographical narratives.

Identity Narratives and Family Life: Identification, Distancing and Social Tensions.

One particular element that emerges in the work of scholars like Alleyene (2000) or Nolas et al. (2016) is the understanding that identity narratives are a product of social tensions and personal contradictions. Identity narratives are problematic and messy, they relate to how activists understand the influence of early childhood and family life. At the same time these narratives are shaped by activists' perception of a wide variety of political cues that emerge in their encounter with others throughout their life. These cues can be drawn from their experience of the historic and political context, the institutions they cohabit, or the lived experience of specific - and often traumatic - political events.

During my research amongst the Autonomous group in Italy, for instance, all these different dimensions came into life as activists discussed their life histories in relation to their political development. What surprised me, was the fact that activists' identity narratives were often very similar. In fact, after discussing the influence family life played in the shaping of their political selves, they would reflect on the social injustice they felt as they were growing up within an Italian political context, whose democratic promise had been hacked by the neoliberal and hegemonic monopoly of Silvio Berlusconi. They also talked about the first political experiences within 'institutional' settings such as high-school and universities or recalled traumatic experiences - such as the police brutality of the Genoa 2001 G8 demonstrations. Consequently, activists referred to different political experiences and social contexts when defining themselves politically, which included and situated family life within a broader political-historic context.

The understanding that identity narratives are shaped by messy and complex processes of narrative construction - which not only bring together elements of family life with other key social experiences but also include forms of selfrecognition and self-distancing from specific relationships - shares some similarities with Hegel's understanding of the making of political identities. As Moland (2011) has suggested, Hegel believed that political identity develops from within the family and within civil society. He also argued that if we look at the role of the family in processes of identity construction we need to appreciate the fact that individuals develop the capacity to decide, which inherited traits or qualities they want to endorse (2011:37). Therefore, in order to understand the complexity of the making of political subjects we need to take into account how activists continuously shape their identity narratives through open-ended processes of approximation and distancing from the political values learned in the family as they reflect on these values in relation to other values and social experiences learned through civic engagement. 
AUTHORS's Proofs May 2017. To cite: Barassi Veronica..2017 'Digital Citizens? Data Traces and Family Life', selected for the Special Issue on Activism across the Life Span, Contemporary Social Science Journal. 12 (1-2), pp.84-95, ISSN 2158-2041

These open-ended and complex processes of self-construction, are not linear, rational and conscious, but rather are affective and contradictory. Once we understand this complexity, we can turn our attention to an important transformation that is impacting on family life at the moment: the rapid proliferation of digital storytelling practices and the everyday construction of political identities online. The next part of the paper will thus explore the nuances and complexities of these processes and will argue that scholars have much to gain if they turn their attention on how digital storytelling within family life is raising new questions about digital participation and the making of digital citizens.

\section{Digital Storytelling: between Self-Construction and the Political Profiling of Others}

\section{Digital Activism and the Construction of the Online Political Self}

In understanding the relationship between political identities, digital storytelling and biographical narratives we are faced with two fundamental problems. On the one hand, within the study of digital activism different scholars have focused mostly on processes of collective identity construction (Kavada, 2015; Tere, 2015; Milan, 2015) and very little attention has been placed on the relationship between political self-construction, digital storytelling and family life.. On the other hand, within communication research we have seen the emergence of different studies that have focused on digital storytelling in a variety of ways, yet they have overlooked the complex relationship between the lived experience of political activists and digital storytelling. The edited collection by Lundby (2008), for instance, brings together different approaches to digital storytelling with some scholars focusing on how digital storytelling has emerged in collective offline contexts whilst others looking at more individualised forms of storytelling on live blogs and social media. Within the collection little attention is placed on the relationship between political activism and digital storytelling. One exception to this is the chapter by Couldry (2008), whose article explores the relationship between political participation and digital storytelling. Through the concept of 'alternative publics' (Toft and Bennett, 2008), Couldry reflects on the relationship between 'voice' and democratic emancipation. This is to detriment, however, of a careful analysis of the relationship between political activism, selfconstruction, and digital storytelling.

In this regard, the work of Vivienne (2016) is particularly insightful. Vivienne (2016) shows not only that activists engage in digital storytelling as a powerful way of building their political identities but also that they use different 
AUTHORS's Proofs May 2017. To cite: Barassi Veronica..2017 'Digital Citizens? Data Traces and Family Life', selected for the Special Issue on Activism across the Life Span, Contemporary Social Science Journal. 12 (1-2), pp.84-95, ISSN 2158-2041

platforms to make different identities coexist. This understanding emerged very clearly from my own research. During my research, I carried out a digital ethnography of activists' Facebook profiles, and analysed how activists' Facebook timelines enabled practices of self-construction through digital storytelling. The digital ethnography also highlighted the fact that there was a bound relationship between these online practices of self-representation and family life. Through the digital ethnography, I realised that there were two different, yet interconnected ways in which activists referred to early childhood and family life as a way to construct their online political identities.

On the one hand, activists uploaded old images of childhood, and created a textual narrative around this images that was highly political. On their Facebook profiles, therefore, photos of themselves attending demonstrations or direct actions were at times juxtaposed with images of themselves as smiley toddlers and faces covered in chocolate. What fascinated me about this digital practice is the fact that through posts and playful interactions with friends and social networks, these early childhood images were often framed in political terms. The black and white photograph of a three-year old wearing denim dungarees, and standing with her legs apart is read by those commenting on the photo as an example of political determination. The image of a group of boys (probably ten or eleven-year-old) standing on a rock near a lake in what looks like the open countryside, is followed by different social media interactions on the importance of environmental activism at a very young age. What was surprising about these digital practices was the fact that when specific political references were missing, comments mentioned the 'style' of the time and would refer to the politicalhistorical context, such as Thatcherism and the miner strike, or the terrorism of the 1980 s in Italy.

If on the one hand activists framed childhood images in political terms to construct their identity narratives, on the other they posted images of their family members and discursively constructed these images by presenting their family members as political and moral agents. Mothers, sisters, uncles, were captured during demonstrations and political rallies, and framed with comments that related to their political commitment. Photos of grandmothers or great uncles, were often followed by comments on the role they played in the resistance movement in Italy during the Second World War. Again, when explicit political references were missing, activists discussed the moral qualities of their family members, their social commitment and engagement with the community or other socially significant activities. What is particularly interesting about these practices is the fact that these processes of self-construction with reference to family ties are not linear and simple, but involve a series of social tensions. In fact, often activists used these platforms to negotiate the political tensions 
AUTHORS's Proofs May 2017. To cite: Barassi Veronica..2017 'Digital Citizens? Data Traces and Family Life', selected for the Special Issue on Activism across the Life Span, Contemporary Social Science Journal. 12 (1-2), pp.84-95, ISSN 2158-2041

emerging with family bonds. On the Facebook profile of an activist, for instance, there is the image of a group of elders sitting in a hospice. She has titled the image 'visiting granny' and in the caption, she criticises her grandmother and her friends for their racist remarks. Another activist, instead, used the social media platform to reflect on the loss of his grandparents and to make public the fact that despite their clear political differences he perceived them as key agents in his political formation.

\section{Digital Storytelling and the Political Profiling of Family Members}

Both examples shed light on the fact that the digital construction of early childhood and family life, therefore, played a fundamental role in the shaping of activists' online identity narratives through storytelling. These processes of online negotiation through digital storytelling are a vivid example of what has been discussed above in relation to the complexity of identity narratives, and the fact that these narratives are shaped by a dual process of self-recognition and selfdistancing from family bonds. Yet they also shed light on the fact that the construction of one's own political identity on social media with reference to family life involves the construction of the political identity of others. This is particularly evident if we consider the representation of children. Over and over again during the digital ethnography I had to come to terms with the fact that activists' Facebook timelines were filled with images of their own children or the children of other family members and friends. By sharing images and personal identifying information of these children, activists constructed their political profiles by making visible their family of origin's political history and the political values. In addition to this, activists discursively constructed these children as political agents. On the Facebook profile of Paul ${ }^{3}$, an activist involved in the British Trade Union Movement, for instance, there is a picture of his toddler son sitting on the floor together with another boy. The caption of the image reads: 'discussing the details of their vanguard party'. This is not an isolated example. During my research, I came across posts of children at demonstrations holding banners and flags, children playing together and being described as 'plotting the next revolution', children with signs openly criticizing the current government or supporting specific political campaigns. It is clear that there is a playful and joking dimension in the posts. However, critical questions emerge about these 'political' associations.

Activists digital practices, in fact, revealed that through digital storytelling they not only constructed their political identities but they also constructed the political profiles of other family members by sharing personally identifying political data. These digital micro- practices, as the next and final part of the paper

\footnotetext{
${ }^{3}$ Fictional Name to protect the participant's anonymity
} 
AUTHORS's Proofs May 2017. To cite: Barassi Veronica..2017 'Digital Citizens? Data Traces and Family Life', selected for the Special Issue on Activism across the Life Span, Contemporary Social Science Journal. 12 (1-2), pp.84-95, ISSN 2158-2041

will show, shed light on the fact that we need to create new theoretical models that enable us to understand the making of digital citizenship across the life course and re-think existing models of political participation.

\section{The Making of Digital Citizenship: From the Engaged Citizen to the Datafied Self}

One particularly problematic element that emerges in the construction of online political identities, today, through digital storytelling is represented by the notion of "web presence" as developed by Leaver (2015), who has rightly argued that one of the key problems of current discussions on online identity, is the assumption that users have an agency in the shaping of their digital profiles. Yet this is not entirely true. The notion of "web presence" therefore is particularly useful in the context of family life because it enables us to appreciate the fact that digital identities are not only constructed by the subject/user, but are often constructed by others.

As argued above, my research revealed that activists not only share personal identifying information of their family members online, but discursively construct them as political and moral agents. Through the sharing of posts and tagging of images therefore they play an active role in the definition of the digital profiles of their family members. These digital interactions that are widespread within family life, and which appear to be harmless and playful - may be transforming the lived experience of digital participation and hence the making of digital citizens across the life course. This is not only because being able to appropriate personal data flows means being able to represent ourselves in public but also because the production of digital traces within family life need to be understood with reference to broader processes of surveillance and archiving of citizen's personal data.

Within the social sciences, digital citizenship has often been defined as an empowering, positive concept, used to describe how humans participate in society through digital media (Mossberger et al., 2007; Ohler, 2010; Barron et al, 2014). However, in the last years, a growing body of research has shown that with the rise of big data the concept of digital citizenship is increasingly becoming more problematic. From social media to mobile apps, from institutions to governments, citizens are forced to digitally participate in society because their personal information is digitised, shared, stored, analysed and exploited for them by others. In this context digital citizenship is often constructed by the different digital traces that we willingly or unwillingly leave behind in our everyday digital interactions, or that others create for us (Isin and Ruppert, 2016; Dencik and Hinz, 2016; MacCosker et al, 2016). At present, therefore, key questions are emerging on how the concentration, organisation and storage of personal identifying 
information is leading to the construction of citizens as quantified selves (Lupton, 2016). The aim of this paper was to start addressing these questions. As it has been shown, activists everyday social media practices talk directly about the experiential and relational processes of data production. Through practices of digital storytelling activists did not only construct their own political narratives, but also constructed the political narratives of others. Shedding light on these relational processes and on how digital traces may be defining the civic and political profiles of generations to come, therefore, has become a key priority in research on political participation and civic engagement across the life course.

\section{Conclusion}

This paper aimed to shed light on political activists' complex processes of identity narrative construction. Drawing on Pratt's (2003) notion of identity narratives, the paper has shown that activists often construct their online political biographies with reference to early childhood and family life. These practices of digital storytelling on social media, are particularly important to the study of political activism. This is because they not only highlight how activists' identity narratives today are often negotiated on these platforms, but also how these digital constructions enable the digital profiling of different family members. We do not know whether the personal data that we produce today on social media is going to be available in the future. Yet, it is reasonable to assume that the digital production of personal data will continue to be an aspect of our societies in the next decades, and that the digital surveillance of citizens will be strengthened by new practices of governance (Lyon, 2014). Therefore, starting to question how everyday digital practices build the data futures of generations to come is, today, more important than ever. As it can shed light on how digital participation and digital citizenship are being transformed by our complex data cultures.

\section{References}

Acock, A. C., \& Bengtson, V. L. (1978). On the Relative Influence of Mothers and Fathers: A Covariance Analysis of Political and Religious Socialization. Journal of Marriage and Family, 40(3), 519-530. https://doi.org/10.2307/350932 
AUTHORS's Proofs May 2017. To cite: Barassi Veronica..2017 'Digital Citizens? Data Traces and Family Life', selected for the Special Issue on Activism across the Life Span, Contemporary Social Science Journal. 12 (1-2), pp.84-95, ISSN 2158-2041

Alleyne, B. (2000). Personal Narrative \& Activism: A Bio-ethnography of 'Life Experience with Britain'. London: Goldsmiths College.

Askew, K., \& Wilk, R. R. (Eds.). (2002). The Anthropology of Media: A Reader. Malden, MA: Wiley-Blackwell.

Bailey, J., \& Steeves, V. (2015). EGirls, ECitizens: Putting Technology, Theory and Policy Into Dialogue with Girls' and Young Women's Voices. University of Ottawa Press.

Baker, K. L. (1974). The Acquisition of Partisanship in Germany. American Journal of Political Science, 18(3), 569-582.

https://doi.org/10.2307/2110632

Brauchler, B., \& Postill, J. (2010). Theorising Media and Practice. Oxford ; New York: Berghahn Books.

Barassi, V. (2015). Activism on the Web: Everyday Struggles Against Digital Capitalism (Hardback). New York, NY: Routledge. Retrieved from http://www.bookdepository.com/Activism-on-Web-VeronicaBarassi/9780415717915

Barassi, V., \& Treré, E. (2012). Does Web 3.0 come after Web 2.0?

Deconstructing theoretical assumptions through practice. New Media \& Society, 14(8), 1269-1285. https://doi.org/10.1177/1461444812445878

Barron, B., Gomez, K., Martin, C. K., \& Pinkard, N. (2014). The Digital Youth Network: Cultivating Digital Media Citizenship in Urban Communities. MIT Press.

Bennett, W. L., \& Toft, A. (2008). Identity, Technologies and Narratives: Transnational Activism and Social Networks. In A. Chadwick, P. of P. S. \& C.-D. of the N. P. C. U. A. Chadwick, A. P. of C. P. N. H. Assoc, \& P. N. Howard (Eds.), Routledge Handbook of Internet Politics (pp. 246258). Routledge.

Cammaerts, B., Mattoni, A., \& Mccurdy, P. (2013). Mediation and Protest Movements. Bristol, UK; Wilmington, NC, USA: Intellect.

Castells, M. (2012). Networks of Outrage and Hope: Social Movements in the Internet Age (1 edition). Cambridge, UK; Malden, MA: Polity Press.

Connell, R. W. (1972). POLITICAL SOCIALIZATION IN THE AMERICAN FAMILY: THE EVIDENCE RE-EXAMINED. Public Opinion Quarterly, 36(3), 323-333. https://doi.org/10.1086/268014

Dahlgren, P. (2009). Media and Political Engagement: Citizens, Communication and Democracy. Cambridge University Press.

Day, R. J. F. (2005). Gramsci is Dead: Anarchist Currents in the Newest Social Movements. London; Ann Arbor, MI : Toronto: Pluto Press.

Dencik, L., \& Hintz, A. (2016). Digital Citizenship in an Age of Mass Surveillance. Re:Publica Berlin. Retrieved from https://republica.com/de/file/republica-2016-lina-dencik-arne-hintz-digitalcitizenship-age-mass-surveillance 
AUTHORS's Proofs May 2017. To cite: Barassi Veronica..2017 'Digital Citizens? Data Traces and Family Life', selected for the Special Issue on Activism across the Life Span, Contemporary Social Science Journal. 12 (1-2), pp.84-95, ISSN 2158-2041

DeWalt, K. M., \& DeWalt, B. R. (2002). Participant Observation: A Guide for Fieldworkers. Rowman Altamira.

Escobar, A. (2004). Identity. In D. Nugent \& J. Vincent (Eds.), A Companion to the Anthropology of Politics, (pp. 248-267). Malden, MA: Blackwell Pub.

Fenton, N. (2016). Digital, Political, Radical. Malden, MA: Polity Press.

Gerbaudo, P. (2012). Tweets and the Streets: Social Media and Contemporary Activism. London: Pluto Press.

Ginsburg, F. D., Abu-Lughold, L., \& Larkin, B. (Eds.). (2002). Media Worlds: Anthropology on New Terrain. Berkeley: University of California Press.

Hastrup, K., \& Davis, J. (1992). History and the People without Europe. In Other Histories (pp. 1-14). London; New York, N.Y: Routledge.

Hess, R. D., Torney-Purta, J. V., \& Valsiner, J. (2005). The Development of Political Attitudes in Children. New Brunswick, NJ: Aldine Transaction.

Holloway, J. (2002). Change the World without Taking Power: The Meaning of Revolution Today. London; .

Isin, E., \& Ruppert, E. (2015). Being Digital Citizens. London, UK ; New York: Rowman \& Littlefield International.

Jennings, M. K. (1984). The Intergenerational Transfer of Political Ideologies in Eight Western Nations*. European Journal of Political Research, 12(3), 261-276. https://doi.org/10.1111/j.1475-6765.1984.tb00088.x

Kavada, A. (2015). Creating the collective: social media, the Occupy Movement and its constitution as a collective actor. Information, Communication \& Society, 18(8), 872-886. https://doi.org/10.1080/1369118X.2015.1043318

Liebes, T., \& Ribak, R. (1992). The Contribution of Family Culture to Political Participation, Political Outlook, and Its Reproduction. Communication Research, 19(5), 618-641. https://doi.org/10.1177/009365092019005004

Lundby, K. (2008). Digital Storytelling, Mediatized Stories: Selfrepresentations in New Media. Peter Lang.

Lupton, D. (2016). The Quantified Self. John Wiley \& Sons.

Mattoni, A. (2012). Media Practices and Protest Politics How Precarious Workers Mobilise by Mattoni, Alice ( AUTHOR) Jun-28-2012 Hardback. Ashgate Publishing Group.

McCosker, A., Vivienne, S., \& Johns, A. (2016). Negotiating Digital Citizenship: Control, Contest and Culture. Rowman \& Littlefield Publ Grou.

Moland, L. L. (2011). Hegel on Political Identity: Patriotism, Nationality, Cosmopolitanism. Northwestern University Press.

Mossberger, K., Tolbert, C. J., \& McNeal, R. S. (2007). Digital Citizenship: The Internet, Society, and Participation. Bellingham, Wash: The MIT Press. 
AUTHORS's Proofs May 2017. To cite: Barassi Veronica..2017 'Digital Citizens? Data Traces and Family Life', selected for the Special Issue on Activism across the Life Span, Contemporary Social Science Journal. 12 (1-2), pp.84-95, ISSN 2158-2041

Ohler, J. B. (2010). Digital Community, Digital Citizen. Corwin Press.

Papacharissi, Z. (2010). A Networked Self: Identity, Community, and Culture on Social Network Sites. Taylor \& Francis.

Pettifor, H. (2012). Do Parents Affect the Early Political Priorisation of Nature in their Children? Institute for Social and Economic Research. Retrieved from http://s3.amazonaws.com/academia.edu.documents/30494411/201211.pdf?AWSAccessKeyId=AKIAJ56TQJRTWSMTNPEA\&Expires $=147$ $\underline{8027402 \& \text { Signature }=6 \mathrm{I} 56 \% 2 \mathrm{FOH} 3 \mathrm{~s} \% 2 \mathrm{FYxkIzfUzIt} 34 \mathrm{WPHkY} \% 3 \mathrm{D} \& \mathrm{re}}$ sponse-

contendisposition=inline $\% 3 \mathrm{~B} \% 20$ filename $\% 3 \mathrm{DDo}$ parents_affect the e arly_political_pr.pdf

Pratt, J. (2003). Class, Nation and Identity: The Anthropology of Political Movements. Pluto Press.

Postill, J. (2014). Democracy in an age of viral reality: A media epidemiography of Spain's indignados movement. Ethnography, 15(1), 51-69. https://doi.org/10.1177/1466138113502513

Tilly, C. (1994). Afterward: Political Memories in Space and Time. In J. Boyarin (Ed.), Remapping Memory: The Politics of TimeSpace (Minnesota Archive Editions edition, pp. 241-257). Minneapolis: University of Minnesota Press.

Vivienne, S. (2016). Digital Identity and Everyday Activism: Sharing Private Stories with Networked Publics. Springer.

Wolfson, T. (2014). Digital Rebellion: The Birth of the Cyber Left. Urbana:

University of Illinois Press. 